\title{
MET NM_000245.3:c.3689A>G
}

National Cancer Institute

\section{Source}

National Cancer Institute. MET NM 000245.3:C.3689A>G. NCI Thesaurus. Code

C162281.

A nucleotide substitution at position 3689 of the coding sequence of the MET gene where adenine has been mutated to guanine. 